\title{
DEVELOPMENT OF THE NEWER THIOBARBITURA.TES USED IN ANAESTHESIA
}

\author{
J K Rosales, M.D., ${ }^{*}$ R. Denis, M.D., $\nmid$ and R. G. B. GILBerT, M.B., F.R.C.P.(c)革
}

A REVIEW of the history of intravenous anaesthesia makes us wonder why such a method, which started only thirty years (1872) after the successful administration of ether anaesthesia by Long (1842) and Morton (1846), did not become more generally accepted until twenty years ago; and why such a method did not start earlier, when intravenous injection of fluids was first reported about two centuries before that, in 1651 (1). Its slow progress in the past was not due so much to a fallure to appreciate its value as to the lack of suitable and effective agents (2). For that same reason, the search for better agents continues to the present, in spite of the fact that thiopental seems to be enjoying universal acceptance.

A number of drugs have been administered intravenously for the production of general anaesthesia. None proved completely satisfactory until two rapidly acting barbiturates, hexobarbitone (3) and thiopental (4) were introduced. These two substances started a resurge of interest in intravenous anaesthesia.<smiles>CN1C(=O)C(C)(C2CCCC2)C=CC1O[AlH2]</smiles>

SOdITM Hexobarbitone (Evipal)<smiles>[Y19]SC1NC(=O)C(C(C)C)(C(C)CC)N1</smiles>

Sodium Teitopental

The advantage of intravenous anaesthesia is well established. However, the agents in use are not ideal (2). They have undesirable effects on the respiratory and parasympathetic systems, aside from their cumulative action (5). Some barbiturates possess definite stimulating properties, sometimes restlessness and twitching persist throughout the whole course of action making them unsuitable for use as hypnotics. Stimulating properties of barbiturates show also as laryngospasm during the introductory phase of intravenous barbiturate anaesthesia (6).

Lund reported his experience with thiamylal sodium (Surital Sodium) (7).<smiles>[Y15]SC1NCC2(C(C)CC=C)CC2N1</smiles>

Thiamylal Sodium (Surital)

"Department of Anaesthesı, Montreal Children's Hospital and McGill University.

†Hôpital Notre-Dame, Montreal, Quebec.

ŁDepartment of Anaesthesıa, Montreal Neurological Institute, Queen Mary Veterans' Hospital and McGrll Unversity 
This did not gain popularity as it did not show convincing advantage over thiopental.

Several hundred $\mathrm{N}$-methyl nitrogen barbituric acid derivatives were synthesized, hoping that the replacement of the oxygen by sulfur andl alkylation of nitrogen might produce a drug of shorter action than thiopental. Unfortunately, the shorter duration is accompanied by frequent untoward side effects. The toxicity and duration of 4-N-methyl derivatives were found similar to thiopental and thiamylal in the same species (8). It was also shown that they have less cumulative action than their parent thiobarbiturates, suggesting a more rapid rate of breakdown. Stoelting and others $(9,10)$ studied five of these drugs clinically. They reported that two of these drugs (no. 14694) N-methyl thiopental and (no. 16193) N-ethyl thioseconal appear to produce hypnosis without undesirable side effects-contrary to the accepted theory that all $\mathrm{N}$-methyl barbiturates display convulsive or even excitatory properties.<smiles>CCCC(C)C1(CC)C(=O)NC(=S)N(C)C1=O</smiles>

DRUG NO 14694

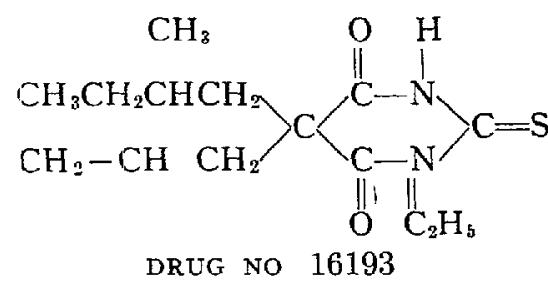

DRUG NO 16193

N-Methyl and N-Ethyl ThIobarbiturates

The use of others of this group was discontinued owing to the severe complications encountered (hiccoughs, laryngospasm, etc.). They found these drugs had half the duration of action of thiopental in dogs, while in man narcosis was extremely profound and of very brief duration. Fapper and others (11) have shown that the shorter duration of $\mathrm{N}$-methyl thiopental compared to thiopental is due to its greater affinity for body fat.

Sodium N-ethyl 5 allyl $5^{\prime}$ (2 methyl butyl) 2-thiobarbiturate is less potent in man than is methyl-thiopental. Other compounds have been tried, but the incidence of side effects such as laryngospasm and hiccoughs and occasional hypotension was so great as to exclude the possibility of them being of any clinical value.

In 1950, fifty spiro-barbituric acid derivatives and trials of the four "promising compounds" were reported by Swanson and others (12).<smiles>[R4]C1C([R4])C([R])C2(NC(=S)N([Y])C2=O)C1[R]</smiles>

\begin{tabular}{rcccc} 
No. & \multicolumn{1}{c}{$\mathrm{R}$} & $\mathrm{R}_{1}$ & $\mathrm{R}_{2}$ & \multicolumn{1}{c}{$\mathrm{R}_{3}$} \\
14 & $\mathrm{CH}_{3}$ & $\mathrm{C}_{2} \mathrm{H}_{5}$ & $\mathrm{H}$ & $\mathrm{H}$ \\
18 & $\mathrm{C}_{2} \mathrm{H}_{5}$ & $\mathrm{C}_{2} \mathrm{H}_{5}$ & $\mathrm{H}$ & $\mathrm{H}$ \\
26 & $\mathrm{CH}_{3}$ & $\mathrm{CH}_{3}$ & $\mathrm{H}$ & $\mathrm{CH}_{3}$ \\
36 & $\mathrm{CH}_{3}$ & $\mathrm{C}_{2} \mathrm{H}_{5}$ & $\mathrm{H}$ & $\mathrm{CH}_{3}$
\end{tabular}


Typical anaesthetic effects were observed when two substitutes were introduced into the alicyclic ring of spiro-butane, spiro-pentane and spiro-hexane derivatives. The four spiro-thiobarbiturates were studied and reported to be. effective anaesthetic agents. Occasionally however, recovery was slightly slower than following thiopental; retching, hiccoughs, coughing and muscle tremor occurred more frequently with nos. 18 and 26. Like thiopental, all four lowered blood pressure, increased pulse rate, depressed respiration, but did not inhibit vagal response to electrical stimulation. Volpitto (13) used a spiro-thiobarbiturate (Spirothal) (spiro-2-ethyl-3,5-dimethyl cyclopentane-5,5-pyramidine-2-thio-4,6-dione sodium) with decamethonium for endotracheal intubation. A rather high incidence of laryngospasm and bronchospasm was reported with this combination.

Because none of these drugs showed conclusive evidence of improvement over thiopental, other drugs are presently being investigated.

\section{Methitural Sodtum (Neraval ${ }^{*}$ Sodium)}

About two years ago, a new ultra-short acting intravenous anaesthetic with significantly more rapid recovery and fewer side effects than thiopental and thiamylal sodium was reported by European investigators. This drug, methitural sodium (Neraval Sodium) is known as "Thiogenal" in Europe.

\section{Chemistry}

Methitural sodium (Neraval Sodium)-sodium 5 (1 methylbutyl) 5-2-(methylthio) ethyl-2 thiobarbiturate is unique because of the presence of the methylthio-<smiles>CCCC1CC(C)C1C(=O)NC(=O)n1[nH]c(=O)[nH]1</smiles>

Methitural Sodium (Neraval Sodium)

ethyl radical $\left(\mathrm{CH}_{3}-\mathrm{S}-\mathrm{CH}_{2}-\mathrm{CH}_{2}\right)$, which is a radical found in methionine-an

$$
\begin{gathered}
\mathrm{CH}_{2}-\mathrm{S}-\mathrm{CH}_{2}-\mathrm{CH}-\mathrm{COOH} \\
\mathrm{NH}_{2}
\end{gathered}
$$

Methionine

essential amino acid, important in the process of detoxification (14) and once used to reduce to the mininmum protein catabolism during anaesthesia (15). This explains its ultra-short action; due to rapid destruction and elimination by liver and kidneys.

\section{Physical Properties}

It is a pale yellow, hygroscopic powder buffered with anhydrous sodium carbonate. It has a pH about 9.8 and is compatible with Flaxedil, d-tubo curare and succinylcholine. 


\section{Pharmacology}

The anaesthetic potency is two-thirds that of thiopental. Given in equivalent doses there is more rapid recovery. Cumulative action is negligible as compared to other drugs. It appears to have no synergistic action with atropine, morphine sulphate, succinylcholine or d-tubo curare.

Respiratory system. Spasm, cough and hiccough were found to be frequent when the drug was given in high concentration (5-10 per cent solution). Similar findings occurred when this drug, though more dilute was given rapidly. None occurred when 0.5 per cent drip with nitrous oxide and oxygen was used. Dillon and co-workers (14) reported that there was more salivation with Neraval than with thiopental. They state that its action is more parasympathomimetic than those of other barbiturates. Houde and others (16) showed that the introduction of an oro-pharyngeal airway did not give rise to any reflex disturbance even at light stages of anaesthesia. Erwin and co-workers (17) advocate premedication to include atropine because it appears to diminish or abolish salivation and coughing and seems to potentiate the depth and duration of anaesthesia.

Circulatory system. A report by Houde and co-workers (16) states that the systolic blood pressure drops $20-30 \mathrm{~mm}$. Hg while diastolic remains unchanged; the pulse rate increases with this fall of blood pressure then returns quickly to normal. There occurs a generalized vasodilation as with other barbiturates. The colour of the skin remained normal and erythema was not seen. They considered that surgical haemorrhage was not more pronounced than usual, on the contrary, it seemed less. Whether this was due to the hypotension was not mentioned.

Riffin and Black (18) made electrocardiographic studies on patients given Neraval. The electrocardiogram was recorded during induction in fifty unselected cases. The changes compared favourably with those seen during thiopental or thiamylal anaesthesia.

Central nervous system. There were no chills, convulsions, mydriasis or agitation observed by Houde and others (16). They found that recovery was rapid and complete. There was no vertigo.

The drug has been used for electroconvulsive therapy (19). It was then reported that muscle rigidity may result, being most easily detected in the lower jaw and upper extremities This was followed by varying degrees of muscle relaxation depending on the depth of anaesthesia. It did not alter the convulsive threshold. However, it influenced the type of seizure in that there were less intense tonic contractions and clonic movements which latter terminated abruptly. It appeared to shorten the period of seizure but not the period of post-seizure apnoea. Most important, they found that the recovery time was minimal. There was no hangover and the patients left the office within 20 minutes; when other barbiturates were given, the patients did not leave before 45-90 minutes. They mentioned that patients with asthma, severe hypertension or hypotension, mild cardiac decompensation and extreme obesity withstood the treatment well under anaesthesia.

All seem agreed that the side effects are less when concentrations less than 5 per cent are used, and most advocate the use of dilute solutions for procedures lasting more than half an hour. 


\section{ButhaLITONE SODIUM}

Another thiobarbiturate that is being investigated is transithal (Baytinal, Buthalitone). This was first described by Miller et al. (20) in 1936 and its pharmacology was investigated by Weese and Koss in experimental animals (21).

\section{Chemistry}

It is sodium 5-allyl-5' isobutyl barbituric acid.<smiles>CCCCCCCCCC(C)CC(C)CC(C)C</smiles>

\section{Physical Properties}

It is a yellowish powder with a slight smell, easily soluble in water. It is alkaline and is clinically used as a 10 per cent solution.

\section{Pharmacology}

Weese and Koss claimed the drug to be superior to other thiobarbiturates regarding its rapid recovery; however, they found it less potent. They found a dose of $500 \mathrm{mgm}$. was necessary to induce anaesthesia. Although most investigators emphasize its ultra-short action, Nobes (22) mentioned after his series that "delayed recovery is a drawback and therefore the drug cannot be unreservedly recommended for routine use." On the other hand, he says if it is used for induction and supplementary nitrous oxide is used, a smooth and rapid recovery can be predicted far more confidently than with other intravenous agents used in the same way. He mentions that postoperative drowsiness was not usually, severe but was much more common when the patient had had premedication.

Respiratory system When injected rapidly, sneezing, coughing and retching occurred. Respirations were slowed and reduced in depth. These returned to normal within two minutes, while operative stimulation increased depth and rate.

Cardiovascular system. The systolic blood pressure drops with little change in the diastolic. Slight bradycardia occurred during induction. These blood pressure changes returned to normal 4-5 minutes after start of injection and the pulse rate within 2 minutes. It is interesting to note that Ruddell (23) mentions "once the blood pressure starts to rise, it appears that the patient is ready for operation."

Central nervous system. The drug was given to a volunteer (22) $(600 \mathrm{mg}$ was injected slowly over a period of $1 \frac{1}{2}$ minutes). Drowsiness occurred, followed by rapid loss of consciousness. After a further $1 \frac{1}{2}$ minutes, $400 \mathrm{mg}$. was injected quickly. Painful stimuli then increased the depth and rate of respiration. This could be a sign of its poor analgesic property. The subject regained consciousness after 6 minutes without mental confusion. There was no retrograde amnesia. After 
a further 6 minutes he was able to walk straight, and within 22 minutes wrote an account of the subjective sensations. Slight euphoria persisted for about 2 hours. Transithal has been used for "narco-relaxation" (24) where tension is a prominent feature. In divided doses and injected slowly it was noted that the patient first felt the effect $1 \frac{1 / 2}{2}$ minutes after the start of injection, experiencing much relief of tension and a feelnng of well-being. There was controlled relaxation without impairment of consciousness and sleep was produced by increasing the rapidity of injection. It was also noted that if the drug was withheld for a minute or two, the patient returned to consciousness. No side actions were noted, neither was excitement seen.

Other effects. There was no alteration in blood volume. The initial blood pressure drop is attributed to a decrease in the blood flow in the relaxed muscles. As in the case of hexobarbitone, there was little effect on the blood sugar. The blood coagulation was unaffected. Evidence from animal experiments suggests that the drug should not be given intramuscularly (21). This drug has also been used in electroconvulsive therapy, when it was found that doses of 250-500 mg. injected over one-half minute caused less depression than thiopental, and that patients speedily returned to consciousness. It was further stated that side actions such as hiccoughs and retching were no more common than with thiopental.

\section{Methitural Sodium (Neraval ${ }^{\circledR}$ ): Personal Cases}

Following encouraging reports of others, we investigated some of the properties of Neraval (methitural sodium). The intention was to use it mainly for anaesthesia during electroconvulsive therapy, with the purpose of evaluating some of its pharmacologic actions, particularly its relaxant effect, if any. In order to augment our series, it was also used in varıous minor surgical operations such as incision and drainage, and reduction of fractures and dislocations. No attempt was made to select the type of patient. The majority of patients were between the ages of $60-69$ years.

\section{Technique}

The patients for electroconvulsive therapy were premedicated with the usual dose of atropine one hour before anaesthesia. No barbiturate or opiate was given with the atropine. A 2.5 per cent solution of Neraval alone was used for all these patients. A higher concentration was not used because of previous reports of others on the incidence of side effects such as spasms, cough and hiccoughs. Oxygen alone was administered during these very short procedures. Cases which were going to last more than ten minutes were given a continuous infusion of 0.6 per cent Sodium Neraval solution supplemented by 50 per cent nitrous oxide and oxygen.

\section{Results}

One of the first characteristics of the drug noted was the long lag between start of injection and effect of the drug, so that there was a tendency to give 
more drug than it was considered the patient actually needed for the procedure. There was a high incidence of laryngospasm and coughing when the drug was injected rapidly, but none occurred when the required quantity of drug was injected over a period of not less than 45 seconds.

Less salivation followed the electroconvulsive therapy under Neraval compared to those cases anaesthetized with sodium amytal alone. This was very significant because most of those patients done under other barbiturates had profuse salivation during and after the shock, with resulting cyanosis and coughing. Such was not the case in the surgical patients, as no marked salivation occurred in those operated on under other barbiturate anaesthesia. The patients maintained a very good colour throughout the procedure. This may well be due to the fact that these patients received 100 per cent oxygen prior to the shock.

Hiccoughs almost always appeared after the shock, lasting on an average five minutes, and disappearing spontaneously

Apnoea was related to the dose given. At the beginning of the series, when more drug was given than was needed, there was an average apnoea lasting 2 to 3 minutes.

Some relaxation was definitely produced as evidenced by the fact that tonic and clonic contractions were never violent. This gave the impression that some curare-like drug had been given with it.

The recovery period was definitely rapid. Most of the patients were able to answer questions before they were returned to their wards.

More definite observations were made on the surgical patients as there was no other condition with them which might affect the patient, as the electro-shock does.

(1) The respiration was definitely depressed during anaesthesia. In a few patients the depression simulated that of morphine.

(2) Analgesic property was poor.

(3) Systolic blood pressure fell appreciably-about $20-30 \mathrm{~mm}$. $\mathrm{Hg}$, although there was less change in the diastolic blood pressure.

It is not certain whether the above observations were due to over-dosage or not. An attempt was made to use the drug alone, and it is quite probable that it was used to a point of over-dosage which produced the above findings.

The most impressive property of Neraval was the rapid recovery. Patients were awake and coherent within 15-20 minutes.

\section{SUMMARY}

An attempt has been made to show the slow progress of intravenous anaesthesia. Some of the newer thiobarbiturates which have been and are being evaluated have been reviewed. A preliminary report of cur experience with methitural sodium (Neraval Sodum) is presented. It seems that the only definite advantage it has over those presently used is the rapid recovery. Before one can even predict whether this drug will have a definite place in anaesthesia, it must be subjected to more rigorous studies. 


\section{ACKNOWLEDGMENTS}

Our thanks are due to Dr. Campbell McG. Gardner, Chief of Surgery, Queen Mary Veteran's Hospital, and members of his department for their co-operation, to Dr. T. E. Dancey, Chief of the Department of Psychiatry, Queen Mary Veteran's Hospital; to the recovery room staff, Queen Mary Veteran's Hospital, Montreal, for their assistance in recording post-anaesthetic conditions.

The methitural sodium (Neraval Sodium) used in this study was supplied through the courtesy of Schering Corporation Limited, Montreal, Quebec.

\section{RÉSUMÉ}

Tout en montrant les progrès lents de l'anesthésie intraveineuse, nous avons voulu, au cours de ce traval, faire une brève revue des différents thiobarbituriques et plus spécialement du Néraval qui a été l'objet de recherches récentes.

En effet, ll y a environ deux ans, un nouveau barbiturique à action ultracourte était connu sous le nom de Néraval. Cette nouvelle substance est surtout remarquable parce qu'elle permet un réveil plus rapide qu'avec le pentothal ou le surital.

Le Néraval contient le radical méthylthioéthyl que nous trouvons également dans la méthionine, un acide aminé essentiel important dans le processus de détoxification. Ceci explique son action ultra-courte due à sa destruction rapide et à son élimination par le foie et les reins.

A la suite de rapports encourageants, nous avons décidé d'employer le Néraval comme anesthésique de base au cours des anesthésies pour électrochocthérapie au lieu d'amytal ou de pentothal. Notre intention était de voir s'il donnait ou non un certain relâchement musculaire (curare-like). Nous avons d'abord remarqué que la coloration des patıents anesthésiés au Néraval était toujours rosée contrairement à ceux qui recevaient de l'amytal ou du pentothal. Un certain degré de relâchement a été définitivement constaté donnant même l'impression qu'une dose de succinylcholıne aurait: été donnée en même temps. En effet, les contractions toniques et cloniques ne furent jamais violentes après injection de Néraval.

Le réveil était beaucoup plus rapide qu'avec les autres substances employées, cependant que nous avons noté un temps assez long entre le début de l'injection du Néraval et la perte de conscience.

Nous avons remarqué une diminution nette des sécrétions salivaires après. les électrochocs si nous comparons avec des patients anesthésiés à l'amytal.

Cependant, nous avons noté une assez forte proportion de toux et de laryngospasme léger quand le Néraval était injecté rapidement, incident évitable en injectant lentement.

Le Néraval a été employé aussi comme anesthésique de base au cours de diverses autres interventions mineures avec des résultats satisfaisants.

La principale propriété du Néraval est certes de permettre un réveil rapide. Cependant avant de prédire que cette drogue aura une place définie en anesthésie, nous crovons qu'elle devra être soumise encore à de rigoureuses études. 


\section{REFERENCES}

1 Gwathmey, J T General Anesthesia Historical Highlights in Its Development. Hygeia $14 \cdot 109-12$ ( Feb , 1936).

2 Adanrs, R. C Intravenous Anaesthesia, p. 457. New York: Paul B Hoeber, Inc. (1944).

3 Weese, H, \& SchrapfF, W. Evipan, eln nerrantiges Einschlaffmittal. Deutsche med. Wchnschr. 58: 1205-7 (July, 1932).

4 Lundy, J. A. Intravenous Anesthesia Prelıminary Report on the Use of Two New Throbarbiturates Proc Staff Meet, Mayo Clinic. 10 536-43 (Aug. 21, 1935).

5 Brodie, B. B, Bernstein, E, \& Mark, L C. The Role of Body Fat in Limiting the Duration of Action of Thiopental J Pharmacol. \& Exper. Therap. 105: 421 (Aug, 1952).

6 Richands, R. K. Studies on "Convulsive" Thiobarbiturates. Anesth. \& Analg. 30: 348-52 (Nov-Dec., 1951).

7. Lụnd, P. C Surital Soduum Intravenous 6000 Consecutve Cases. Aneșth. \& Analg. 30. 86 (March-Aprl, 1954).

8 Swanson, E E, \& Cuen, K K. Proc Soc Exper. Biol, N Y. 82.212 (1953)

9 Stoelting, V K. Cllnical Use of Newer Intravenous Barbiturates in Anesthesiology. Anesth \& Analg. 32370 (1953).

10 Stoelting, V. K, \& Graf, J P. Preliminary Report of Five New Intravenous Barbiturates Anesthesiology 15.61 (1954)

11. Papper, E M., Peterson, R. C., Burns, J. J, Bernstein, E, Lief, P. \& Brodie, B. B. Anesthesiology, 16:544 (1955).

11 Paper, E. M, Peterson, R. C., Burns, J. J, Bernstein, E., Lief, P, \& Brodie, B. B. Anesthesiology 16544 (1955)

12 Swanson, E E, Mueller, L B, Henderson, F G., \& Chen, K. K. Anesth \& Analg. $2989(1950)$.

13 Volpitro, P Anesthesiology 12.648 (1951)

14 Boone, John D, Munoz, Raphael, \& Dimlon, John B Neraval Sodium: A New UltraShort-Acting Throbarbiturate Prelıminary Clinical Investıgations. Anesthesiology 17 . 284 (March, 1956)

15 Harris, T. A B The Mode of Action of Anesthetics, P. 497 Edinburgh E. S. Livingstone Ltd (1951)

16 Houne,- J, Hunson, F, \& Jacques, A Neraval (Methitural Sodium) Canad Anaes. Soc J 443 (Jan, 1957)

17 Irwin, S, StagG, R. D, Dunbar, E, \& Govier, W. M J Pharmacol \& Exper. Therap. Il6 325 (March, 1952).

18 RifFin, I, \& Block, M Induction of General Anesthesia with a New Ultra-Short Acting Agent, Methitural Sodium Electrocardiographic Studies Presented at Annual Meeting of the Medical Society of New Jersey, May 15, 1956.

19 Ayd, F Neraval A New Anesthetic for Electroconvulsıve Therapy. Progress Record from Dr Ayd, Baltimore, Md

20 Miller, E, Munch, I, Crossby, F, \& Hartung, W J Am. Chem. Soc, 58. 1090 (1936).

21. Weese, H, \& Koss, F. H Deutsche med: Wchnschr. 79601 (1954).

22. Nobes, $P$ New Short Actıng. Thiobarbiturate. Lancet, p 797 (April 16, 1955).

23 Shecog Ruddeld, J New Short Acting Thiobarbiturate. Lancet, p 1138 (Nov. 26, 1955)

24 McColt. M G. Baytınal in Psychatry Lancet, p. 93 (July 9, 1955). 